Tarbawi: Jurnal Ilmu Pendidikan p-ISSN:1858-1080 | e-ISSN: 2615-6547 Vol. 17, No. 1, June 2021, 83-93

\title{
The Correlation of Soft Skills and Hard Skills to Learning Outcomes of Mathematics Students
}

\author{
Dini Palupi Putri \\ Institut Agama Islam Negeri Curup \\ dinigusnadi@gmail.com
}

\begin{abstract}
The goal of the 2013 curriculum is to develop the next generation of citizens who have positive personality traits, can contribute to social life, and can compete in life in the future. It necessitates not just hard skills but also soft skills, which the future generation must acquire. The purpose of this research is to examine the link between students' soft skills and hard talents. The research method is employed in quantitative research. This study's sample consists of Mathematics Education students for the 2019/2020 school year. Questionnaires and tests are employed as tools. According to the questionnaire data, the soft skills of the Mathematics Education Study Program students at IAIN Curup were in a good category, namely 53.125 percent. The hard skills of the Mathematics Education Study Program students at LAIN Curup were also in a good category, namely 50 percent. According to the bypothesis test, there is no link between students' soft skills and hard skills to learning outcomes. Students' soft skills development may be applied to activities both inside and outside of the classroom and an integrated curriculum that includes both hard skills and soft skills. Student involvement in groups with practical activities is critical to enhancing adaptability, teamwork, tolerance, discipline, and responsibility.
\end{abstract}

Keywords: Hard Skills, Learning Outcomes, Mathematics Students, Soft Skills

\section{INTRODUCTION}

The goal of developing the 2013 curriculum is stated in Decree of Ministry of Education and Culture Number 69 of 2013 concerning the Basic Framework and Curriculum Structure of Senior High Schools/Madrasah Aliyah, which is to prepare Indonesians to live as individuals and citizens who are faithful, productive, creative, innovative, effective, and capable of contributing to the life of society, nation, state, and world civilization (Kemendikbud, 2013). This aim necessitates the next generation of the nation having excellent personal character, participating in social life, competing in life in the future, and having both hard and soft abilities. The government continues to develop so that the nation's future generation can compete after finishing their education and be valuable to the nation and state.

We frequently face incidents of ethical transgressions in this global and digital world. Numerous technical breakthroughs, especially in our period, cannot prevent the admission of undesirable things that might spread among the following generation. The growth in occurrences of rule infractions indicates that the nation's character has deteriorated, implying that reforms in education are required. Students must be proficient not only in hard skills but also in soft skills.

Mathematics Education Study Program at IAIN Curup is a new study program that began in 2017. There are two batches of students enrolled in the Mathematics Education Study Program: the 2017/2018 class and the 2018/2019 class. With this newly created study program, students will benefit from forming and developing soft and hard skills from the start. Education mathematics students who want to be math instructors must have both hard and soft talents. Because the soft and hard skills were built throughout college, they can later become professional 
staff for their pupils after entering the sector. As a result, they will produce students with strong hard and soft talents in the future.

The message emphasized the significance of honesty and good character in today's digital age. Good character is required in this century since the digital era is rife with information (data) that is beneficial and deceptive. Therefore honesty in data utilization is essential (Minarni, Napitupulu, \& Kusumah, 2020). The capacity of soft skills determines a person's success in the workplace. When preparing to enter the workforce, a mix of soft and hard abilities must be maintained. As a result, the curriculum used in lecture activities must develop soft skills and complex abilities.

The mastery of science, technology, and technical abilities relating to science is referred to as hard skills (Alfiansyah, Jamal, \& An'nur, 2014). The ability to acquire mathematics by using hard skills is the ability to solve mathematical problems. Students must be able to answer abstract mathematical problems, but they must also comprehend mathematical ideas relevant to everyday life to address issues frequently faced so that the information learned becomes meaningful.

Soft talents include non-technical meanings, abilities that can supplement academic abilities, and abilities that everyone must have. Students' soft skills in mathematics learning must be enhanced. One of the soft skills of studying mathematics is the capacity to communicate. Communication skills are frequently practiced in continuous lectures, such as in paper presentations or presentations for final thesis assignments, transmitting thoughts and concepts in oral and written form, and converting ideas into a product, the outcome of the theory studied. Teamwork is an example of soft skill competence development found in lecture activities, in which students collaborate in groups to accomplish project tasks assigned by lecturers. Students with strong soft and hard skills are more likely to achieve high final assessment ratings. As a result, students who want to be teachers have done their homework before embarking.

According to Bartik (Santia, 2016), the association between Soft Skills and learning outcomes is quite tight. Soft Skills may give substantial support to a person's growth and development and speedy influence on early childhood. A strong association between Hard Skills and learning outcomes is also revealed in the findings of his research, which show that Hard Skills have a significant influence on Prakerin students' performance. The findings of the two previous research indicate a significant association between hard and soft skills and student learning outcomes. The goal of this study is to examine how students possess soft and hard skills and serve as assessment material for lecturers on which indications of students' soft and hard skills need to be improved and developed. It also examines the link between soft and hard skills and student learning outcomes.

\section{METHOD}

This study is quantitative. The purpose of this study is to assess the number of links between soft skills and learning outcomes and the level of relationship between hard skills and learning outcomes. A saturated sample of 16 third-semester students and 16 fifth-semester students was used in the sampling process. Questionnaires and documentation were used as research instruments in this study.

Students' soft skills and hard skills are assessed using a questionnaire instrument, with indicators for Soft Skills including honesty, responsibility, fair dealing, ability to work together, adaptability, communication skills, tolerance, respect for others, decision-making ability, and problem-solving ability. ability in the realm of information technology Mathematical talents, which comprise mathematical knowledge, mathematical reasoning abilities, mathematical problem-solving abilities, mathematical communication skills, mathematical connection abilities, and mathematical critical thinking skills, are markers of students' hard skills. Documentation on the previous semester's student GPA is gathered from study program officials to examine learning results. 
The students' soft skills and hard skills surveys were assessed qualitatively and approved by material, language, and presentation experts. According to the results of the expert validation, there are some question items from the questionnaire's linguistic aspect that must be altered. The questionnaire had been amended in response to the validator's comments before being delivered to the sample.

The descriptive data analysis approach examines the average score and categories (very good, good, adequate, and deficient). These categories are derived from the questionnaire findings' ideal average and ideal standard deviation. Students' soft skills and hard skills The Pearson correlation test was used to examine hypotheses with the assistance of SPSS. The normality of the data was checked using SPSS before testing the hypothesis.

\section{FINDINGS}

\section{Student's Soft Skills}

Data on students' soft skills are gathered using a questionnaire with up to 36 question items. The questionnaire findings show that the lowest score is 101, the highest score is 160 , the average score is 131.125 , and the standard deviation is 12.6. The variable-frequency distribution for Soft Skills is as Table 1.

Table 1 . Soft Skills Ability Frequency Distribution

\begin{tabular}{cccc}
\hline No. & Interval & Frequency & Percentage \\
\hline 1 & $101-110$ & 2 & 6.25 \\
\hline 2 & $111-120$ & 2 & 6.25 \\
\hline 3 & $121-130$ & 11 & 34.375 \\
\hline 4 & $131-140$ & 12 & 37.5 \\
\hline 5 & $141-150$ & 2 & 6.25 \\
\hline 6 & $151-160$ & 3 & 9.375 \\
\hline & Total & 32 & 100 \\
\hline
\end{tabular}

The researcher also gives the findings of the questionnaire based on the categories based on the data in Table 1 of the frequency distribution above; the following are the results of the Soft Skills ability category of Students:

Table 2. Category of Student Soft Skills

\begin{tabular}{cccc}
\hline Interval & Number of Students & Percentage & Category \\
\hline $\mathrm{X}>145,2$ & 3 & 9,375 & Very good \\
\hline $130,5<\mathrm{X} \leq 145,2$ & 14 & 43,75 & Good \\
\hline $115,8<\mathrm{X} 130,5$ & 11 & 34,375 & Adequate \\
\hline $\mathrm{X} \leq 115,8$ & 4 & 12,5 & Deficient \\
\hline Total & 32 & 100 & \\
\hline
\end{tabular}

Based on the calculation of the soft skills ability category described in the table and diagram above, the percentage obtained for each category is 9.375 percent for the perfect category, 43.75 percent for the excellent category, 34,375 percent for the Adequate category, and 12.5 percent for the deficient category. In other words, more than half of students have soft skills abilities in the good and very excellent categories, whereas half of the students have soft skills questionnaire responses in the sufficient and not good categories.

The findings of the soft skills questionnaire are also described using soft skills indicators. Table 3 shows questionnaire data for each student's soft skills indicator.

Table 3. Data Description of Each Student Soft Skills Indicator 


\begin{tabular}{cc}
\hline Soft Skills Indicators & Mean \\
\hline Communicating Ability & 3,406 \\
\hline ICT proficiency & 3,052 \\
\hline Problem Solving Ability & 3,395 \\
\hline Responsibility & 3,822 \\
\hline Adaptability & 3,708 \\
\hline Honesty & 3,989 \\
\hline Act Fairly & 3,921 \\
\hline Cooperation Capability & 3,953 \\
\hline Tolerant & 3,796 \\
\hline Respect for Others & 4,070 \\
\hline Decision-Making Ability & 3,843 \\
\hline
\end{tabular}

Table 3 shows that the average score for completing the questionnaire based on the soft skills indicators is 3-4, indicating that the Soft Skills of each indication are already in the excellent range. The indicator of respect for others has the highest frequency of the average value of the Soft Skills questionnaire findings, with an average value of 4.07 , while the ability indicator in the field of ICT has the lowest frequency of the average value of the soft skills questionnaire results.

The Soft Skills indication of competence in the field of ICT is the first responsibility for lecturers, students, and study programs to enhance and grow based on the findings of the average value per indicator. Other soft skills markers, on the other hand, must be enhanced and developed.

\section{Student's Hard Skills}

Data on students' hard skills were gathered using a questionnaire with up to 30 question items. The histogram of the hard skills variable frequency is as follows. Based on the questionnaire findings, the soft skills questionnaire yielded the lowest score of 80 and the highest score of 125, with an average score of 103.34 and a standard deviation of 8.7. Following that, compute the number of intervals using the formula $1+(3.3) . \mathrm{N}$ is the number of samples, and $\log \mathrm{N}$ is the number of samples. $(1+3.3) 1.5 * 6.45=$ The number of obtained intervals is six. $(125-80)$ data range $=45$, class length $=45: 6=7.5=8)$. The frequency distribution of Soft Skills variables is shown in Table 4.

Table 5. Frequency Distribution of Hard Skills Ability

\begin{tabular}{cccc}
\hline No. & Interval & Frequency & Percentage \\
\hline 1 & $80-87$ & 6 & 18,75 \\
\hline 2 & $88-95$ & 8 & 25 \\
\hline 3 & $96-103$ & 4 & 12,5 \\
\hline 4 & $104-111$ & 8 & 25 \\
\hline 5 & $112-119$ & 5 & 15,625 \\
\hline 6 & $120-127$ & 1 & 3,125 \\
\hline & Total & 32 & 100 \\
\hline
\end{tabular}

The percentage in each ability category interval may be calculated based on the computation of the hard skills ability category and detailed in Table 4. The percentages for each category are 18.75 percent for very good, 31.25 percent for good, 12.5 percent for adequate, and 37.5 percent for deficient.

In other words, $50 \%$ of students with hard skills abilities fall into the perfect categories, whereas $50 \%$ of students with hard skills questionnaire scores fall into the sufficient and deficient categories.

Based on these findings, it is possible to conclude that the students' hard skills ability is quite good; however, it is also necessary to develop hard skills for them to be further improved; efforts to develop students mathematics' hard skills can be carried out in the local learning process by designing appropriate learning to improve hard skills. 
Researchers must also give the data from the questionnaire responses observed from the hard skills indicators to determine which indicators are most managed by students and which indicators are not mastered by students. The questionnaire data for each student's hard skills indicator is shown in Table 5.

Table 5. Data Description of Each Student's Hard Skills Indicator

\begin{tabular}{lc}
\hline \multicolumn{1}{c}{ Soft Skills Indicator } & Mean \\
\hline Comprehension Ability & 3,648 \\
\hline Reasoning Ability & 3,475 \\
\hline Problem-solving skill & 3,031 \\
\hline Communication Ability & 3,294 \\
\hline Connection Ability & 3,242 \\
\hline Creative Thinking Ability & 3,006 \\
\hline
\end{tabular}

The student hard skills questionnaire's average score from the hard skills indicators is described in Table 5. Mathematical knowledgeability, mathematical reasoning capacity, mathematical problem-solving ability, mathematical communication ability, mathematical connection ability, and mathematical creative thinking ability are among the hard skills indications.

Table 6 shows that the average score for completing the questionnaire based on the hard skills indicators is 3-4, indicating that the hard skills of each indication are already in the excellent range. The indicator of mathematical understanding ability has the highest frequency of average hard skills questionnaire results, with an average value of 3,648. The indicator of creative thinking ability has the lowest frequency of average hard skills questionnaire results, with an average value of 3,006 .

Based on the average value per indicator, the hard skills indication is the capacity to think creatively, which is the first duty for lecturers, students, and study programs to enhance and grow. Other hard skills markers, on the other hand, must be improved and developed.

\section{The Correlation of Students' Soft Skills and Learning Outcomes}

The results from the soft skills questionnaire were verified for normality using the Kolmogorov Smirnov Test, which was aided by SPSS software. The Assymp Sig Kolmogorov Smirnov value reached $>5 \%$ significance threshold, namely 0.510, from the Kolmogorov Smirnov Normality Test calculation results. As a result, it is possible to conclude that the two variables, soft skills, and student learning outcomes, are regularly distributed.

The correlation hypothesis test employs the Pearson Connection test, aided by SPSS version 21, to determine whether or not the two variables have a correlation and the magnitude of the correlation.

Table 6. Pearson Correlation between Hard Skills and Learning Outcomes

\begin{tabular}{cccc}
\hline & & Soft Skills & GPA \\
\hline \multirow{3}{*}{ Soft Skills } & Pearson Correlation & 1 &,- 093 \\
\cline { 2 - 4 } & Sig. (2-tailed) & &, 614 \\
\cline { 2 - 4 } & $\mathrm{N}$ & 32 & 32 \\
\hline \multirow{3}{*}{ GPA } & Pearson Correlation &,- 093 & 1 \\
\cline { 2 - 4 } & Sig. (2-tailed) &, 614 & 32 \\
\cline { 2 - 4 } & $\mathrm{N}$ & 32 &
\end{tabular}

Table 6 shows that the estimated Pearson Correlation Test result attained the Assymp Sig Pearson Correlation value $>5 \%$ significance threshold, which is 0.614 . As a result, the two variables, namely soft skills and student learning outcomes, might be inferred to be uncorrelated or unconnected. 


\section{The Correlation of Students' Hard Skills with Learning Outcomes}

Data normality was tested using the Kolmogorov Smirnov Test, which was aided by SPSS software. The Kolmogorov Smirnov Normality Test results yielded the Assymp Sig Kolmogorov Smirnov value $>5 \%$ significance threshold, 0.950 . As a result, it is possible to conclude that the two variables, hard skills, and student learning outcomes, are regularly distributed.

Table 7 shows the results of the Correlation test between the Hard Skills factors and learning outcomes. This correlation hypothesis test uses the Pearson Connection test, aided by SPSS version 21, to determine whether or not the two variables have a correlation and the magnitude of the correlation.

Table 7. Pearson Correlation between Hard Skills and Learning Outcomes

\begin{tabular}{cccc}
\hline & & Hard Skills & GPA \\
\hline \multirow{3}{*}{ Hard Skills } & Pearson Correlation & 1 & $551^{* *}$ \\
\cline { 2 - 4 } & Sig. (2-tailed) & 32 &, 001 \\
\cline { 2 - 4 } GPA & $\mathrm{N}$ & $551^{* *}$ & 32 \\
\cline { 2 - 4 } & Pearson Correlation &, 001 & 1 \\
\cline { 2 - 4 } & Sig. (2-tailed) & 32 & 32 \\
\hline **. Correlation is significant at the 0.01 level (2-tailed). & &
\end{tabular}

Table 7 shows that the estimated Pearson Correlation Test value attained the Assymp Sig Pearson Correlation value 5 percent significance level, which is 0.001 . As a result, the two variables, namely hard skills and student learning outcomes, may be determined to be correlated or associated with a moderate correlation category. Table 8 shows the results of the basic Linear Regression calculations to determine the association between the variables $\mathrm{X}$ (hard skills) and $\mathrm{Y}$ (learning outcomes).

Table 8. Simple Linear Regression

\begin{tabular}{ccccccc}
\hline \multirow{2}{*}{ Model } & \multicolumn{2}{c}{ Unstandardized Coefficients } & $\begin{array}{c}\text { Standardized } \\
\text { Coefficients }\end{array}$ & \multirow{2}{*}{ T } & Sig. \\
\cline { 3 - 5 } & & $\mathbf{B}$ & Std. Error & Beta & & \\
\hline \multirow{2}{*}{1} & (Constant) & 2,665 &, 234 & & 11,385 &, 000 \\
\cline { 2 - 5 } & Hard Skills &, 009 &, 002 &, 551 & 3,617 &, 001 \\
\hline
\end{tabular}

a. Dependent Variable: Learning Outcomes

Based on the findings of the regression test in Table 8 , a constant $B$ value of 2,665 and a $\mathrm{B}$ hards skills value of 0.009 was obtained. The regression model developed from these findings is $\mathrm{Y}^{\prime}=2.665+0.009 \mathrm{X}$. According to the model, for every one rise in the value of hard skills, the value of learning outcomes increases by 0.009 . $r$-count $=0.551$, where $r$-count $>r$-table $(0.349)$. According to the findings of this study, if the correlation coefficient $r$-count has a positive value, the two variables have a unidirectional link. Furthermore, it obtained R Square (R2) or a coefficient of determination of 0.304 . The $\mathrm{R}$ Square value in table 22 is 0.304 . This value demonstrates that 30.4 percent of the accomplishment of variable $\mathrm{Y}$ (learning outcomes) can be explained by variable $\mathrm{X}$ (hard skills). In contrast, the remaining 69.6 percent is governed by variables that are not investigated.

\section{DISCUSSION}

\section{Students' Soft Skill}

Students' soft skills are relatively good, but they must be improved continuously. Students' soft skills are developed not only in the lecture process but also in everyday life interactions. 
Moreover, half of the students' soft skills were in the perfect categories, while the other pupils had Soft Skills questionnaire scores in the moderate and bad categories.

The development of soft skills of Mathematics Education Study Program students must be completed and enhanced; this cannot be accomplished overnight. Soft skills development is the primary responsibility of the Mathematics Education Study Program, all of whom must collaborate. Lecturers and students work together to develop and apply positive characteristics in the classroom and the community, including the proper and practical use of science and technology.

Lecture activities contribute to the development and improvement of soft student skills; in lectures, it is critical to select strategies that support psychomotor and affective abilities, both at the beginning of lectures, core activities, and closing activities; lecturers must also be of good character. It is advantageous to be a good role model and to establish a learning tradition of character. According to Muhmin (2018), learning methods are appropriate for use in Soft Skillsbased learning, where Soft Skills are abstract and more in the affective (tasting) and psychomotor (behavioral) domains that are one's skills, then the learning method that should be used by prioritizing an active role and focusing on students (students) and only making lecturers as facilitators.

Figure 1 depicts the results of filling out the questionnaire, which yielded scores of soft skills variable indicators and the categories per indicator.

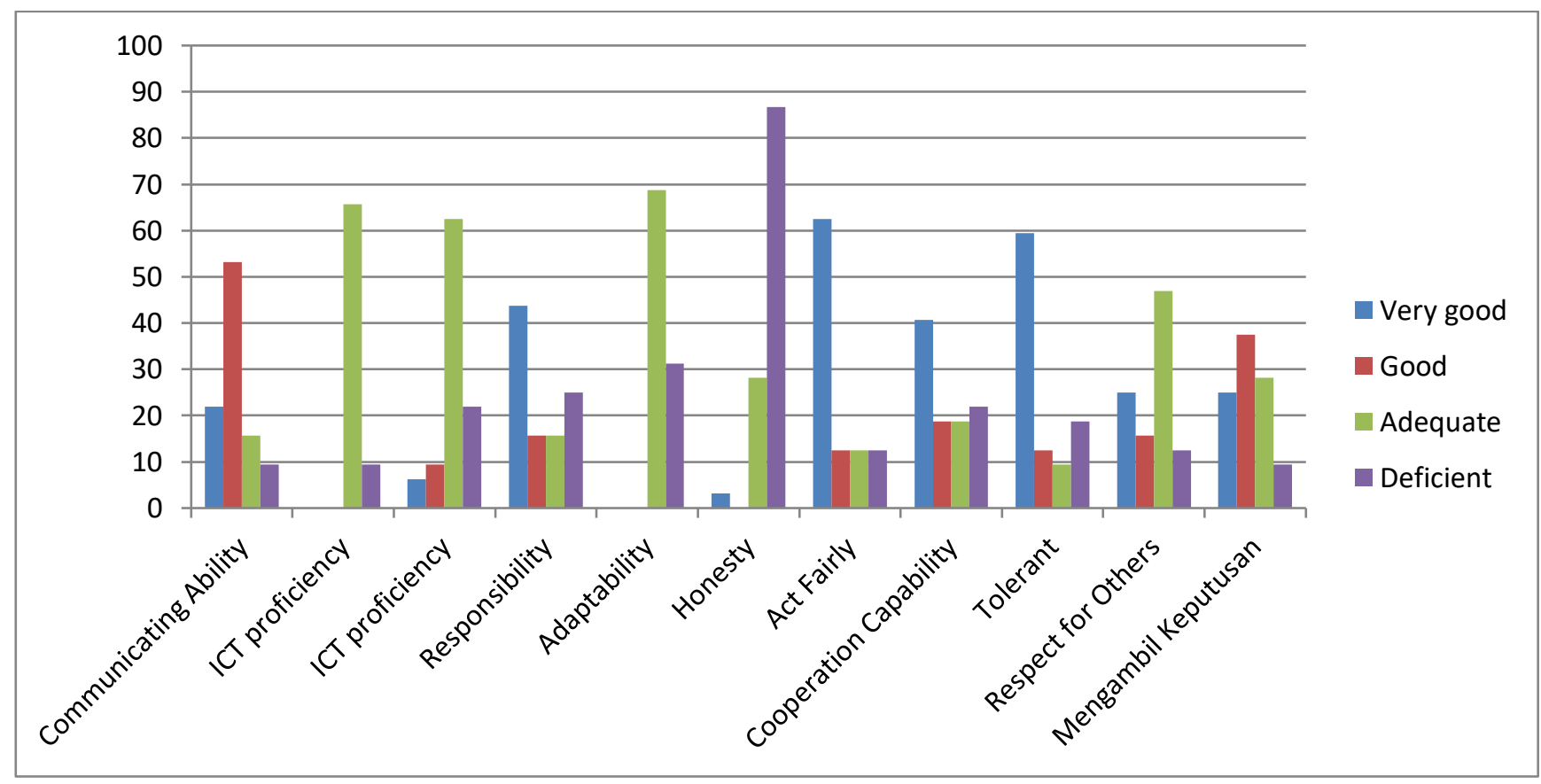

Figure 1. Histogram of Questionnaire Result Categories Hard Skills Indicators

Soft skills indicators, as seen in Figure 1, need to be improved and enhanced. These indicators are markers of ICT ability, problem-solving ability, adaptability, and honesty. Student Soft skills can be developed and improved through campus activities like worship (congregational prayers, Qur'an reading), athletics, and cooperation. Implementation in the curriculum includes soft skills components in the Syllabus, Semester Program Plans, and teaching materials. Implementation in learning, such as planning lecture activities by forming learning groups, such that Soft Skills, such as cooperation, responsibility, adaptability, problem-solving ability, discipline, honesty, and cooperation, appear in learning indicators. Applications in campus culture, such as correctly and adequately contact lecturers and how good the department leader's attitude, how mathematics department personnel serve and give study program amenities. 
The Assymp Sig Pearson Correlation value $>5$ percent significance threshold is 0.614 based on the Pearson Correlation Test computed value. As a result, it is possible to conclude that the two variables, soft skills and student learning outcomes, are unrelated. Since numerous Soft Skills indicators need to be created and enhanced, they are later aligned with student learning objectives. According to the findings of (Sari, Mulyanto, \& Gumay, 2016), there is a strong association between mathematical ability and learning outcomes attained by students in class $\mathrm{X}$ SMA Negeri 3 Lubuk Linggau during the 2015/2016 academic year.

Students' soft skills are developed both in and out of lectures. In lectures, a lecturer integrates the implementation of lectures with Soft Skills indicators that will be developed, whereas outside of lecture hours, students are supported in positive organizational activities to improve their ability to adapt, work together, tolerance, discipline, responsibility, and so on. Sudiana in (Delita, Elfayetti, \& Sidauruk, 2016) formulates the best technique to develop students' Soft and Hard Skills in lectures, and the measures that may be followed are as follows: a) High confidence, an educator must have high confidence for students to be motivated. b) Prepare lecture learning plans. A lecturer must include strategies and methods to build Hard Skills and Soft Skills in lectures. b) Employ appropriate learning methodologies to help students develop their soft and hard skills.

\section{Students' Hard Skills}

The development of hard skills for Mathematics Education Study Program students needs to be improved again. More than half of students receive hard skills ability in the perfect categories, while the remaining half receive hard skills questionnaire scores in the sufficient and not good categories. One way to improve hard skills abilities is to use a problem-based learning model, in which problems are presented first to find concepts, with the problems presented is related to students' daily lives. Problem-based learning teaches pupils how to improve their Hard Skills talents. The problem-based approach promotes creative activities and the development of students' mathematical thinking habits (Suherman et al., 2005).

The findings of the Mathematics Education Study Program students at IAIN Curup filling out the hard skills questionnaire yielded scores of hard skills variable indicators and categories per indicator in Figure 2.

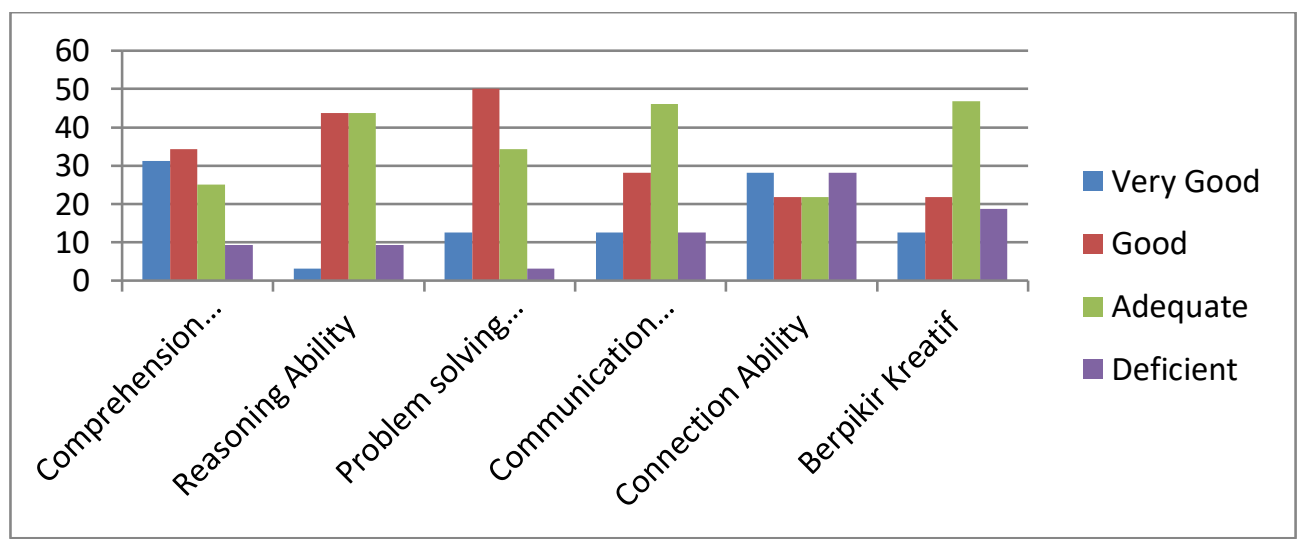

Figure 2. Histogram of Questionnaire Result Categories Hard Skills Indicators

Figure 2 shows that the hard skills indicators are relatively excellent. These indications could be upgraded more for future supplies when students enter the field. These abilities are, of course, intended to help them enhance their professionalism in the future and meet the aims of the profession in which they work.

The value of the calculating results of the Pearson Correlation Test, produced from the questionnaire responses, is the Assymp Sig Pearson Correlation value 5 percent significance level, which is 0.001 . As a result, the two variables, namely soft skills and student learning outcomes, 
may be determined to be connected or related. This research is consistent with the research (Wahyuni, 2016), where the results of the t-test reveal that hard skills and soft skills have a favorable and substantial influence on employee performance. Even if the students' hard skills ability is relatively excellent, this will still be the Mathematics Education Study Program's homework to keep and even grow students' talents. To support this vision, facilities, human resources, and natural resources must all function together.

According to the regression test, hard skills must be enhanced since it accounts for $30 \%$ of the characteristics that increase student learning outcomes. Students can be correctly developed by developing hard skills markers in learning, such as applying rules to non-routine situations, pattern discovery, generalization, and mathematics communication skills. Furthermore, instructors must have strong class management abilities for hard skills to be developed. Class management abilities include the capacity to open and close learning, offer reinforcement, explain, and vary learning.

The function of creative thinking abilities in learning is crucial to improving (Supardi, 2011). Students with a high degree of creative thinking will benefit from internal motivation, which will motivate them to be more engaged in learning mathematics. To obtain strong Hard Skills, educators must enhance the learning process and encourage and guide pupils interested in abstract mathematical content.

Students' ability to do hard skills is pretty excellent. Nonetheless, it is the role of the Mathematics Education Study Program to strengthen and develop students' existing talents. To support this vision, facilities, human resources, and natural resources must all function together. It necessitates cooperation within the academic community in the Mathematics Education Study Program. Satisfactory results will significantly impact the quality of students graduating from the mathematics education study program, allowing students to be readily accepted to work at the institutions of their choice, ensuring that the vision and mission of the Mathematics Education Study Program are met maximally and satisfactorily.

\section{CONCLUSION}

Soft skills ability of Mathematics Education Study Program students at IAIN Curup are in a good category, with 17 students scoring 53.125 percent. The Mathematics Education Study Program students at IAIN Curup have 50 percent of their hard skills in the good category, with 16 students. However, these students' hard skills must be developed and enhanced again such that the proportion is more than $50 \%$. According to the findings, there was no association between the soft skills variable of students and the student learning outcomes of the Mathematics Education Study Program at IAIN Curup.

Students' soft skills development may be applied to activities both inside and outside the classroom, and instructors seek to achieve these aims through lectures. Students can participate in soft skills development activities outside of class hours, such as participating in social events to collect cash for natural disasters, donating blood, and working together to clean mosques. Student involvement in groups with good activities is critical for improving adaptability, teamwork, tolerance, discipline, and responsibility, among other things.

Leaders of study programs might look for a curriculum that combines hard skills and soft skills talents. Efforts are being made to integrate Syllabus, Lesson Plans, instructional materials, and media to improve hard and soft skills. Furthermore, the study program's leadership implements routine regulations that foster hard skills and soft skills, such as praying dhuha every Friday. Leadership efforts and support are critical in building students' hard skills and soft skills talents. 


\section{REFERENCES}

Alfiansyah, M., Jamal, M. A., \& An'nur, S. (2014). Meningkatkan Hard Skills dan Soft Skills Siswa Melalui Model Pembelajaran Koooperatif Tipe STAD. Berkala Imiah Pendidikan Fisika, 151160.

Aly, A. (2017). Pengembangan Pembelajaran Karakter Berbasis Soft Skills di Perguruan Tinggi. Ishraqi, Volume 1 No 1 , 40-51.

Arifin, S. (2015). Implementasi Pembelajaran Berbasis Masalah untuk Meningkatkan Soft Skills Mahasiswa Pendidikan Matematika UIN Raden Fatah Palembang. Jurnal Pendidikan Matematika Rafa, 63-76.

Arnata, I. W. (2014). Evaluasi Soft Skills dalam Pembelajaran Mahasiswa Baru di Fakultas Teknologi Pertanian Teknologi Pertanian Universitas Udayana. Jurnal Pendidikan dan Pembelajaran, Volume 21, Nomor 1, 1-9.

Bagasana, L. (2014). Pengaruh Soft Skills Terbadap Prestasi Praktik Industri Siswa Jurusan Teknik Gambar Bangunan. Yogyakarta: Universitas Negeri Yogyakarta.

Delita, F., Elfayetti, \& Sidauruk, T. (2016). Peningkatan Soft Skills dan Hard Skills Mahasiswa Mellaui Project Based Learnign pada Mata Kuliah Perencanaan Pembelajaran Geografi. Geografi, 124 - 135.

Hendriana, H., Rohaeti, E. E., \& Sumarmo, U. (2017). Hard Skills dan Soft Skills Matematik Siswa. Bandung: Refika Aditama.

Kemendikbud. (2013). Permendikbud RI No 69 tabun 2013, Kerangka Dasar dan Struktur Kurikulum Sekolab MA. Jakarta: Kemendikbud.

Minarni, A., Napitupulu, E. E., \& Kusumah, Y. S. (2020). Perangkat Pembelajaran berbasis Discovery Learning berbantuan Microsoft Excel untuk Meningkatkan Kemampuan Pemecahan Masalah Statistika dan Soft Skills Siswa SMP. KREANO, 1-15.

Muhmin, A. H. (2018). Pentingnya Pengembangan Soft Skills Mahasiswa di Perguruan Tinggi. Forum Ilmiah, 330 - 338.

Nuryana, I., \& Triwahyudiyanto. (2016, 12 03). Pengaruh Soft Skill dan Hard Skill Terhadap Kinerja Siswa Prakerin SMK Modern Al- Rifa'ie. Dipetik 04 28, 2019, dari digilib.uin-suka.ac.id

Putri, D. P. (2017). Pengaruh Pembelajaran Kooperatif Tipe Think Talk Write terhadap Kemampuan Komunikasi dan Pemecahan Masalah. BELAJEA: Jurnal Pendidikan Islam, 7698.

Santia, I. (2016). Peningkatan Soft Skill Mahasiswa Calon Guru Matematika Melalui Critical Lesson Study. JURNAL PED AGOGLA, 157-168.

Sari, D. E., Mulyanto, A. B., \& Gumay, O. P. (2016). Hubungan Antara Kemampuan Matematika 
dengan Hasil Belajar Siswa dalam Pembelajaran Fisika. Lubuk Linggau: STKIP PGRI Lubuk Linggau.

Sobandi, B. (2008). Implementasi Pengintegrasian Hards Skills dan Soft Skills dalam Pembelajaran. Padang: Universitas Negeri Bung Hatta.

Sri, H. (2009). Kemampuan Berpikir Kreatif Matematis. Prosiding Seminar Nasional Penelitian. Pendidikan dan Penerapan MIPA. Yogyakarta: Fakultas MIPA, Universitas Negeri Yogyakarta.

Sudjana, N. (2011). Penilaian Hasil Proses Belajar Mengajar. Bandung: Remaja Rosdakarya.

Suherman, E., Turmudi, Suryadi, D., Herman, T., Suhendra, Sufyani, et al. (2005). Strategi Pembelajaran Matematika Kontemporer. Yogyakarta: UPI.

Sumarmo. (2003). Prosedur Penelitian Suatu Pendekatan Praktek. Jakarta: Bumi Aksara.

Syarifah, L. L. (2017). Analisis Kemampuan Pemahaman Matematis pada Mata Kuliah Pembelajaran Matematika SMA II. JPPM vOL.10 No.2, 57-71.

Titikusumawati, E. (2014). Modul Pembelajaran Matematika. KEMENAG: Program Dual Mode System (DMS).

Supardi, U. S (2011). Peran Berpikir Kreatif dalam Proses Pembelajaran Matematika. Jurnal Formatif, 248 - 262.

Wahyuni. (2016). Pengarub Soft Skills dan Hard Skills Mahasiswa terhadap kinerja pegawai pada dinas pendidikan. Makassar: UIN Alaudin Makassar.

Widarto. (2011). Pengembangan Soft Skills Mahasiswa Pendidikan Advokasi. Yogyakarta: Paramitra. 